\title{
Jellyfish biochemical composition: importance of standardised sample processing
}

\author{
T. Kogovšek ${ }^{1,2, *}$, T. Tinta $^{1}{ }^{1}$ K. Klun ${ }^{1}$, A. Malej ${ }^{1}$ \\ ${ }^{1}$ National Institute of Biology, Marine Biology Station, Fornače 41, 6330 Piran, Slovenia \\ ${ }^{2}$ Present address: Graduate School of Biosphere Science, Hiroshima University, 4-4 Kagamiyama 1 Chome, \\ Higashi-Hiroshima 739-8528, Japan
}

\begin{abstract}
Jellyfish play a key role in many pelagic ecosystems, especially in areas of extensive bloom events. In order to understand their role in pelagic food webs and in biogeochemical cycling, the energy stored and the trophic level occupied by jellyfish need to be quantified. To date, the common protocols applied for quantifying jellyfish biomass and analyzing its biochemical composition have been the same as for crustacean zooplankton, despite the difference in the body composition of the 2 groups. With the goal of establishing a uniform and reliable protocol for assessing jellyfish biomass, elemental, stable isotope and amino acid pool composition, we compared several methods commonly used in zooplankton ecology. Our results show that jellyfish dry mass varied with ambient salinity changes, thus giving a poor representation of jellyfish biomass. Moreover, the content of organic matter determined as ash free dry mass was overestimated; it was on average 2.2 times higher when compared to the mass of the retained material after dialysis. Furthermore, we demonstrated that during oven-drying at $60^{\circ} \mathrm{C}$ the protein-rich jellyfish tissue underwent significant changes: samples were (1) depleted in elemental $\mathrm{C}$ and $\mathrm{N}$ and total amino acid pool and (2) enriched in ${ }^{15} \mathrm{~N}$, when compared to freeze-dried samples. We therefore suggest that freeze-drying should be selected over oven-drying before isotope and total amino acid analysis is applied. Overall, the results of this study suggest that the methods used to assess jellyfish biochemical composition should be carefully chosen.
\end{abstract}

KEY WORDS: Scyphomedusae $\cdot$ Biochemical composition $\cdot$ Stable isotopes $\cdot$ Membrane dialysis · Salinity $\cdot$ Amino acid pool composition

\section{INTRODUCTION}

Jellyfish (here considered as Phylum Cnidaria, Class Scyphozoa) are ubiquitous components of pelagic marine ecosystems, and marked changes in their population size can be seen as a natural feature of healthy pelagic ecosystems (Graham et al. 2001). The combined effects of multiple anthropogenic stressors and/or climate change (Molinero et al. 2008, Richardson et al. 2009, Purcell 2012) may disturb the natural oscillations of jellyfish blooming (Condon et al. 2013), leading to a significant increase in jellyfish populations in some coastal areas and large marine ecosystems (Kogovšek et al. 2010, Brotz et al. 2012).
In such pelagic ecosystems the role of jellyfish becomes more important, shifting energy from fish to jellyfish (Uye 2011). As voracious predators they compete with fish for food (Purcell \& Arai 2001), and through predation on fish eggs (Gordoa et al. 2013) and fish larvae (Purcell \& Arai 2001, Sabatés et al. 2010) jellyfish could even impede the recovery of fish stocks in heavily exploited marine ecosystems (Lynam et al. 2006). Furthermore, jellyfish populations can bloom in a relatively short period of time and can attain enormous biomasses. After the decline of such populations, organic material released into the water column from the decomposing jellyfish tissue promote a microbially dominated food web (Con- 
don et al. 2011, Tinta et al. 2012), thus altering ecosystem diversity and function. Large accumulations of jellyfish carcasses at the sea bed are an important source of labile organic material for a wide spectrum of benthic macroorganisms (for a review see Lebrato et al. 2012). Nevertheless, the unconsumed jellyfish material is decomposed by microbes, and oxygen consumption together with remineralization products that accompany the decomposition may further impact the benthic biota (Billett et al. 2006, West et al. 2009, Lebrato et al. 2012).

In order to understand the role of jellyfish in marine food webs and in biogeochemical cycling, especially in regions with increasing jellyfish bloom events, the energy stored and the trophic level occupied by jellyfish need to be quantified. The pattern of energy flows and the efficiency of mass transfer through the food web are reflected in the ratios of biomass between different trophic levels, usually expressed as dry mass or carbon (C) and nitrogen (N) content. Due to the patchy distribution of jellyfish and a lack of suitable sampling techniques (Purcell 2009), it is difficult to estimate their biomass, therefore jellyfish were often neglected in previous studies of trophic interactions and were rarely included in ecosystem models (Pauly et al. 2009). The recent development of new techniques to assess jellyfish abundance/biomass such as hydroacoustics (Alvarez Colombo et al. 2009), aerial observations (Houghton et al. 2006) and routine fishery surveys (assessing jellyfish abundance as by-catch) (Brodeur et al. 2008) have enabled development of time series of the seasonal and spatial distribution of jellyfish biomass and abundance. Nevertheless, very often in ecological models the role of gelatinous organisms in the food web is simplified, considered as a single functional 'jellyfish' group, assumed to have the same diet and to occupy the same trophic level (Pauly et al. 2009). In the near future, this problem might be overcome by an increasing number of studies that apply stable isotopes for analysing the role of gelatinous plankton in planktonic food chains (see Pitt et al. 2009a for a review, Cardona et al. 2012, Syväranta et al. 2012, D'Ambra et al. 2013a).

Despite the fact that numerous data on jellyfish body elemental composition exist (compiled in Lucas et al. 2011), reliable and uniform protocols for jellyfish sample processing are not established. Until very recently the methodology for sample processing and biomass estimation for jellyfish was the same as that for crustacean zooplankton, despite the difference in biochemical composition between the 2 groups. The jellyfish body contains high water and low organic content compared to crustacean plankton. Moreover, dried jellyfish samples contain a large amount of salts in relation to their organic content. Dry mass (DM) and ash free dry mass (AFDM) of jellyfish vary in relation to ambient salinity (Hirst \& Lucas 1998). Additionally, the residual water bound in dry jellyfish material gives an overestimation of organic material and ash content (Larson 1986). Thus, DM and AFDM offer a poor representation of jellyfish biomass. Most commonly, dry mass is determined by drying the material at $60^{\circ} \mathrm{C}$ until constant mass (Harris et al. 2000). The effect of the prolonged exposure of protein-rich jellyfish tissue (Quensen et al. 1981, Malej et al. 1993, Lucas 1994, Pitt et al. 2009b) to elevated temperatures is unknown. Omori (1978) showed a slight loss of organic matter in 4 zooplankton species (a chaetognath Sagitta nagae and 3 copepods species Calanus sinicus, Pleuromamma xiphias and Acartia tonsa) during oven-drying at $60^{\circ} \mathrm{C}$ until constant mass, interpreting it as volatilization of some lipids and amines, as well as the denaturing of proteins. Furthermore, preservation methods and processing might modify the stable isotope composition of the samples. Several studies demonstrated that freezing, the most commonly used method for sample preservation, does not affect stable nitrogen and carbon isotopes values in fish, octopus, anemone, bivalves, kelp and algae (Kaehler \& Pakhomov 2001, Carabel et al. 2009). However, the opposite was suggested by Fleming et al. (2011) in the case of gelatinous plankton: while freezing did not affect $\delta^{13} \mathrm{C}$, the prolonged storage of frozen Aurelia aurita medusae resulted in the enrichment in ${ }^{15} \mathrm{~N}$. Preservation in ethanol affected the $\delta^{15} \mathrm{~N}$ in some species of invertebrates (Carabel et al. 2009, Fleming et al. 2011), while there was no significant change in nitrogen isotope ratio in fish, octopus and kelp (Kaehler \& Pakhomov 2001). In addition to preservation techniques, sample processing might also alter sample stable isotope ratios. For example, dehydration of samples leads to enrichment in ${ }^{15} \mathrm{~N}$ in oven-dried compared to freeze-dried samples (Carabel et al. 2006). Furthermore, lipids are known to be depleted in ${ }^{13} \mathrm{C}$ (DeNiro \& Epstein 1978) and chemical extraction of lipids prior to analysis might be required to account for variable lipid content in tissues (e.g. Syväranta \& Rautio 2010, D'Ambra et al. 2013b). Together, these observations indicate that the effect of sample processing on biochemical composition is taxon specific.

The main objective of our study was to establish a reliable and uniform protocol for the determination of jellyfish biomass (dry mass, ash free dry mass) and biochemical composition. In order to achieve this, 
several methods commonly used in zooplankton ecology as well as to determine jellyfish biomass, elemental, stable isotope and amino acid pool composition were compared and assessed. We introduce a new desalination method into jellyfish sample processing. Finally, we propose a pre-analytical processing protocol for jellyfish according to selected analysis.

\section{MATERIALS AND METHODS}

In order to establish a suitable protocol for the biochemical analysis of gelatinous organisms, several individual sample processing steps were examined. Apart from conventional methods used for zooplankton analysis, some alternatives were proposed. Fig. 1 shows a schematic representation of each individual step.

Jellyfish homogenate (Step 1). Medusae were collected seasonally in coastal waters from a boat or a pier. The organisms were deposited in a plastic container filled with ambient water and stored at a shaded place. The jellyfish were transported to the laboratory within $1 \mathrm{~h}$ after collection. Bell diameter (to $1 \mathrm{~mm}$ accuracy) and wet mass (to $1 \mathrm{~g}$ accuracy) were determined before storing specimens at $-30^{\circ} \mathrm{C}$ (each medusa separately in a plastic zip-lock bag). Chrysaora hysoscella, Pelagia noctiluca and Rhizostoma pulmo medusae (3 to 5 medusae per species) with an average wet mass $( \pm \mathrm{SD})$ of $464 \mathrm{~g}( \pm 487), 534 \mathrm{~g}$ $( \pm 186)$ and $2881 \mathrm{~g}( \pm 1407)$, respectively, were homogenized using an Ultra-Turrax TP 18/10 mechanical

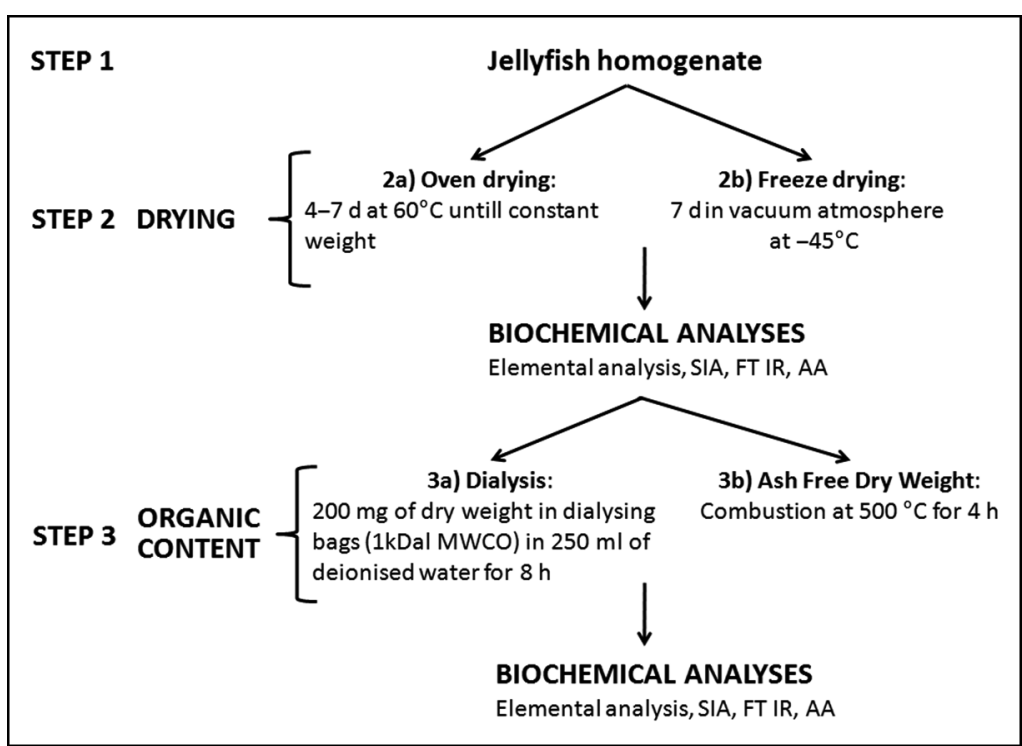

Fig. 1. Schematic representation of the experimental design. MWCO: molecular weight cut off; AA: amino acids; SIA: stable isotope analysis; FTIR: Fouriertransform infrared spectrometry analyses homogenizer (Janke \& Kunkel). Each homogenate was divided into 2 sub-samples of the same wet mass and dried (see Step 2). The organic content in Aurelia aurita was relatively low compared to other species investigated in this study; therefore, the homogenate was not divided into sub-samples. Instead, 10 medusae of similar wet mass (43 $\pm 21 \mathrm{~g}$ ) were unfrozen before they were homogenized individually and the whole volume of each sample was processed and used for further analysis. In order to compare medusae biochemical composition on a higher taxonomic level, individuals of Hydromedusae Aequorea forskalea were collected $(41 \pm 23 \mathrm{~g}, \mathrm{n}=34)$ in addition to 4 scyphozoan jellyfish.

Drying (Step 2). One set of homogenate sub-samples (see Step 1) was poured into pre-weighed aluminium containers and oven dried (OD) at $60^{\circ} \mathrm{C}$ until constant mass (Step 2a). The time required to reach the constant weight was 4 to $7 \mathrm{~d}$. The OD samples were cooled to room temperature in a desiccator and weighed twice per day. The other set of sub-samples was stored at $-30^{\circ} \mathrm{C}$ until freeze-drying (FD samples, Step $2 \mathrm{~b}$ ). The samples were dry after $7 \mathrm{~d}$. Dry mass was determined (to $0.01 \mathrm{~g}$ accuracy) for each set of sub-samples (from Steps $2 \mathrm{a}$ and 2b), calculated and expressed as the total dry mass of the specimen. Afterwards the dried material was homogenized with an agate mortar and pestle and stored in plastic vials at $-30^{\circ} \mathrm{C}$ until further analysis.

Organic content (Step 3). Jellyfish dried material was either combusted in an oven at $500^{\circ} \mathrm{C}$ for $4 \mathrm{~h}$ to determine AFDM, according to the standard protocol for zooplankton (Harris et al. 2000) (Step 3a), or desalted and freeze-dried again (Step 3b). Desalting by membrane dialysis is commonly used in biochemistry when salt ions in the sample interfere with the analyses (e.g. Zhou et al. 1998, Engel \& Händel 2011). During dialysis, molecules in the solution diffuse through a semi-permeable membrane along the concentration gradient. The size of the molecules retained in the sample is defined by the pore size of the membranes (molecular-weight cut off, MWCO). Desalting of dried jellyfish biomass was achieved by membrane dialysis using a dialysis tube with $1 \mathrm{kDa}$ MWCO RC membranes (Spectrapor 7, Spectrum Laboratories). To remove sodium azide preservative, the dialysis tube was soaked in MilliQ water for $1 \mathrm{~h}$ at room temperature before use. Approx. 200 mg 
(400 $\mathrm{mg}$ in the case of A. aurita) of homogenized, dried material was first diluted in $15 \mathrm{ml}$ pre-filtered sea water (GF/F filter with $\sim 0.8 \mu \mathrm{m}$ pore size, Whatman) and poured into a dialyzing tube. The tubes were sealed at both ends with 2 dialysis tubing closers (Spectrapor) and were kept floating in glass beakers containing $200 \mathrm{ml}$ of MilliQ water. The $250 \mathrm{ml}$ glass beakers were put on a shaker $(75 \mathrm{rpm})$ at $4^{\circ} \mathrm{C}$. Salinity was measured with a refractometer every $2 \mathrm{~h}$ just before the water was changed until it reached 0 (after $6 \mathrm{~h}$ ), after that the samples were dialysed for 2 additional $\mathrm{h}$ ( $8 \mathrm{~h}$ in total). Dialysed water (dialysate) was collected in a plastic bottle separately for each dialysed jellyfish sample. Total nitrogen $\left(\mathrm{N}_{\text {tot }}\right)$, nitrate $\left(\mathrm{NO}_{3}\right)$, nitrite $\left(\mathrm{NO}_{2}\right)$ and ammonium $\left(\mathrm{NH}_{4}{ }^{+}\right)$were determined in these water samples according to standard colorimetric methods (Grasshoff et al. 1983) and their modifications (Grasshoff et al. 1999). An empty dialyzing tube submerged in $200 \mathrm{ml}$ of MilliQ water was used as control. The control values were subtracted from the samples dialysate values before $\mathrm{N}$ mass budget was calculated. In order to develop an adequate protocol, additional medusae were freeze-dried and dialysed, after the testing period, to increase the number of data.

Biochemical analyses. Biochemical composition was determined in jellyfish dry homogenate before (Steps $2 \mathrm{a}$ and $2 \mathrm{~b}$ ) and after dialysis (Step 3a) as presented in Fig. 1. Elemental composition of carbon (C), nitrogen $(\mathrm{N})$, hydrogen $(\mathrm{H})$ and sulphur $(\mathrm{S})$ was determined in 5 to $7 \mathrm{mg}$ of dried material after combustion at $1150^{\circ} \mathrm{C}$ (Elementar, Vario Micro Cube elemental analyzer) with $0.1 \%$ accuracy. The results were expressed as the relative amount of individual element per sample. Water of hydration was calculated in accordance with Madin et al. (1981): hydrogen in the bound water was estimated as the difference between the amount of hydrogen measured by elemental analysis and the value calculated as $20 \%$ of the carbon value. Fourier-transform infrared (FT-IR) spectrometry analyses were performed on FD dialysed and non-dialysed samples on a Perkin-Elmer Spectrum One spectrometer with a diffuse reflectance sampling accessory. Samples were diluted with anhydrous $\mathrm{KBr}$ to $10 \%$ final concentration and subsequently filled in a micro-cup accessory. Spectra were scanned 10 times with a resolution of $4 \mathrm{~cm}^{-1}$ in a frequency range of 4000 to $450 \mathrm{~cm}^{-1}$ at room temperature. Subsequently, the ratio of absorption of $\mathrm{N}-\mathrm{H}$ scissoring at $1635 \mathrm{~cm}^{-1}$ and absorption of S-O at $1120 \mathrm{~cm}^{-1}$ was calculated for comparison between jellyfish species. A chromatographic method was used on a homogenized subsample hydrolyzed for $72 \mathrm{~h}$ at $110^{\circ} \mathrm{C}$ in $200 \mu \mathrm{l} 6 \mathrm{~N} \mathrm{HCI} / 1 \%$ phenol for total amino acid analysis (Molecular Structure Facility, UC Davis). The results were calculated and expressed as $\mu \mathrm{g}$ of amino acid per mg of dry mass. Stable isotope analysis was performed in commercial laboratories (Stable Isotope Faculty, UC Davis; and Iso-Analytical Limited). Values were expressed as \% relative to international standards PDB (PeeDee Belemnite) for $\mathrm{C}$, air for $\mathrm{N}$ and Cañon Diablo triolite for $\mathrm{S}$. The precision for internal standards was always better than $0.1,0.3$ and $0.2 \%$ for $\mathrm{C}, \mathrm{N}$ and $\mathrm{S}$, respectively.

Statistical analysis. A 1-way ANOVA was performed to determine the significant differences in biochemical composition between the treatments and between species, followed by Tukey's post hoc comparisons test in the case of significant differences. Relative amounts of $\mathrm{C}, \mathrm{N}$ and $\mathrm{S}$ content were arcsine transformed before ANOVA was applied. When data did not fulfil the requirements of ANOVA, a Kruskal-Wallis test was used. The values of the investigated parameters were expressed as averages with standard deviations given in brackets.

\section{RESULTS}

\section{Oven-drying vs. freeze-drying - the effect on biochemical composition (Steps 2a and 2b)}

The dry mass and the elemental composition of the freeze-dried (FD) samples were higher than those of the oven-dried (OD) samples (Table 1). Despite the significant difference in $\mathrm{C}$ and $\mathrm{N}$ content between the treatments observed for all species (KruskalWallis test, $\mathrm{p}<0.05)$, except for Chrysaora hysoscella, the drying method had no effect on the C/N molar ratio. $\mathrm{C}$ and $\mathrm{N}$ content differed among species (Table 1 , see also Table 3). The lowest values were determined for Aurelia aurita and the highest for Rhizostoma pulmo (ANOVA, p $<0.01$ for the FD samples). $C$. hysoscella and Pelagia noctiluca had similar $\mathrm{C}$ and $\mathrm{N}$ content. The $\mathrm{C} / \mathrm{N}$ molar ratio differed between species and was between 4 and 5 . The average S content of medusae was between 1.5 and $2.7 \%$ (Table 1), being higher for A. aurita and R. pulmo. For A. aurita the relative $\mathrm{S}$ content was higher than $\mathrm{C}$ content. The high $\mathrm{S}$ detected in dried jellyfish homogenate might be due to sulphur incorporated in salts (sulphates) from medusae mesoglea in addition to tissue organic sulphur.

Total amino acid (AA) pool composition of the Scyphomedusae was in accordance with previously reported values (Webb et al. 1972, Quensen et al. 
Table 1. Comparison of biomass (dry mass, DM; dry mass as percentage of wet mass, DM\%WM) and elemental composition (relative amount of $\mathrm{C}, \mathrm{N}$ and $\mathrm{S}$, and $\mathrm{C} / \mathrm{N}$ molar ratio) between oven-dried (OD) and freeze-dried (FD) Scyphomedusae. Mean with SD in parentheses; value in square brackets is number of medusae analysed. Significant difference in elemental composition between treatments: ${ }^{*} \mathrm{p}<0.05$; ns: non significant

\begin{tabular}{|lcccccc|}
\hline $\begin{array}{l}\text { Medusa and } \\
\text { drying method }\end{array}$ & DM (g) & DM\%WM & C (\%) & N (\%) & S (\%) & C/N molar \\
\hline $\begin{array}{l}\text { Aurelia aurita } \\
\text { OD }\end{array}$ & {$[5] 1.88(0.97)$} & {$[5] 4.1(0.1)$} & {$[4] 1.3(0.1)$} & {$[4] 0.3(0.0)$} & {$[4] 2.3(0.2)$} & {$[4] 4.6(0.3)$} \\
FD & {$[4] 1.86(0.74)$} & {$[4] 4.0(0.2)$} & {$[5] 2.0(0.3)^{*}$} & {$[5] 0.5(0.1)^{*}$} & {$[5] 2.6(0.1)^{*}$} & {$[5] 4.7(0.2)^{\mathrm{ns}}$} \\
Chrysaora hysoscella & & & & & & \\
OD & {$[5] 19.08(20.21)$} & {$[5] 4.0(0.3)$} & {$[5] 5.1(3.0)$} & {$[5] 1.4(0.7)$} & {$[5] 1.5(0.6)$} & {$[5] 4.1(0.5)$} \\
FD & {$[5] 18.60(20.27)$} & {$[5] 3.8(0.3)$} & {$[5] 5.4(3.3)^{\mathrm{ns}}$} & {$[5] 1.4(0.8)^{\mathrm{ns}}$} & {$[5] 1.6(0.4)^{\mathrm{ns}}$} & {$[5] 4.5(0.2)^{\mathrm{ns}}$} \\
$\begin{array}{l}\text { Pelagia noctiluca } \\
\text { OD }\end{array}$ & {$[3] 27.45(1.42)$} & {$[3] 4.4(0.1)$} & {$[3] 5.2(0.4)$} & {$[3] 1.5(0.1)$} & {$[3] 1.5(0.2)$} & {$[3] 4.0(0.1)$} \\
FD & {$[3] 26.34(2.23)$} & {$[3] 4.2(0.1)$} & {$[4] 7.9(2.7)^{*}$} & {$[4] 2.2(0.7)^{*}$} & {$[4] 1.8(0.2)^{*}$} & {$[4] 4.1(0.2)^{\mathrm{ns}}$} \\
$\begin{array}{l}\text { Rhizostoma pulmo } \\
\text { OD }\end{array}$ & {$[3] 130.11(62.21)$} & {$[3] 4.5(0.1)$} & {$[3] 7.4(1.6)$} & {$[3] 1.9(0.4)$} & {$[3] 2.4(0.0)$} & {$[3] 4.6(0.2)$} \\
FD & {$[3] 128.16(60.12)$} & {$[3] 4.5(0.1)$} & {$[3] 9.6(1.2)^{\mathrm{ns}}$} & {$[3] 2.6(0.3)^{*}$} & {$[3] 2.7(0.2)^{*}$} & {$[3] 4.4(0.1)^{\mathrm{ns}}$} \\
\hline
\end{tabular}

1981, Malej et al. 1993, Krishnan \& Perumal 2013). Glycine (Gly), glutamic acid (Glx), aspartic acid (Asx), lysine (Lys) and arginine (Arg) were the most abundant AA per unit of dry mass, representing more than $50 \%$ of the total AA pool. Total AA pool composition did not differ significantly between the species. The effect of drying methods on total AA pool composition reflected a similar pattern among different species of Scyphomedusae (Table 2) - the OD samples were depleted in total AA compared to the FD samples. However, due to the high variability, the difference in total AA pool between the 2 treatments was not significant except for Glx, alanine (Ala), tyrosine (Tyr), phenylalanine (Phe), Lys and Arg for R. pulmo (Kruskal-Wallis test, $\mathrm{p}<0.05$ ).

\section{Dialysis vs. ash free dry mass (Steps 3a and 3b)}

In gelatinous organisms, salts represent a significant amount of dry mass with only a small contribution made by organic matter. To remove salts from dried jellyfish, sub-samples of dried homogenate were dialysed. In order to test this new approach, the organic matter mass of the same FD samples was determined using each method (Step 3a and Step 3b).

The mass of organic matter as AFDM in medusae was higher than the dry mass of the dialysed material $(>1 \mathrm{kDa})$ in all 61 analysed samples. On average, the AFDM was $2.2( \pm 0.6)$ times higher than the mass of the dialysed jellyfish material. This ratio differed between species, with the highest ratio of $2.6( \pm 0.7)$ calculated for A. aurita and the lowest for $R$. pulmo
(1.9 [ \pm 0.5$])$. Nevertheless, when the organic content was determined using both methods and it was standardized per unit of dry mass, a significant linear relationship between the 2 parameters was observed (Fig. 2).

The difference between the amount of hydrogen (H) determined by elemental analysis and the amount calculated as $20 \%$ of C content (Larson 1986) was used to estimate the excess water in the samples. The $\mathrm{H}$ content in the dialysed jellyfish material, determined by elemental analysis, ranged from 4.8 to $7.5 \%$ (Fig. 3a). The measured $\mathrm{H}$ content was on average higher than that calculated as $20 \%$ of $\mathrm{C}$ content. The ratio between measured and calculated $\mathrm{H}$ was 2.1 $( \pm 0.9)$ for $A$. aurita medusae, while for C. hysoscella, $P$. noctiluca and for $R$. pulmo it was close to one $(1.1[ \pm 0.2], 1.0[ \pm 0.1]$ and $0.9[ \pm 0.1]$, respectively). The measured amount of $\mathrm{H}$ increased linearly with the increasing amount of $\mathrm{C}$ (slope 0.06 and intersection $4.30 ; \mathrm{r}^{2}=0.60$ ), while the difference between the measured and calculated amount of $\mathrm{H}$ in jellyfish decreased with the increasing amount of $\mathrm{C}$ in the samples (slope -0.14 and intersection $4.30 ; r^{2}=0.90$ ). Similarly, the relative abundance of $\mathrm{S}$ decreased with the increasing $\mathrm{C}$ content (slope -0.30 and intersection $\left.14.25 ; \mathrm{r}^{2}=0.94\right)$ and increased with the increasing difference between measured and calculated $\mathrm{H}$ (Fig. 3b). This suggests that dialysis had not removed the entire inorganic $\mathrm{S}$ and that the surplus of the $\mathrm{H}$ content measured was probably bound in hydrated sulphate or other salts. FT-IR analysis confirmed the presence of sulphate showing strong bands at $1000-1200 \mathrm{~cm}^{-1}$, which is characteristic for the vibra- 
Table 2. Comparison of total amino acid (AA) pool composition ( $\mu$ g of AA in mg of dry biomass) of freeze-dried (FD) and oven-dried (OD) Scyphomedusae. Means (SD in parentheses) of 3 samples per treatment. Asx: aspartic acid; Thr: threonine; Ser: serine; Glx: glutamic acid; Pro: proline; Gly: glycine: Ala: alanine; Val: valine; Ile: isoleucine; Leu: leucine; Tyr: tyrosine; Phe: phenylalanine; His: histidine; Lys: lysine; Arg: arginine. Significant difference between treatments: ${ }^{*} p<0.05$

\begin{tabular}{|lrrrrrrc|}
\hline & \multicolumn{2}{c}{ Chrysaora hysoscella } & \multicolumn{2}{c}{ Pelagia noctiluca } & \multicolumn{2}{c}{ Rhizostoma pulmo } \\
& OD & FD & OD & FD & OD & FD \\
\hline & & & & & & \\
Asx & $10.7(3.9)$ & $12.2(4.5)$ & $5.0(1.3)$ & $6.9(0.5)$ & $8.6(0.7)$ & $8.4(0.6)$ \\
Thr & $5.3(1.8)$ & $6.0(2.1)$ & $2.1(0.7)$ & $3.1(0.1)$ & $4.6(0.4)$ & $4.3(0.3)$ \\
Ser & $5.3(1.9)$ & $6.2(2.2)$ & $1.5(0.4)$ & $2.9(0.1)$ & $3.5(0.2)$ & $3.9(0.3)$ \\
Glx & $15.2(5.4)$ & $17.6(6.1)$ & $4.8(1.5)$ & $10.3(0.6)$ & $9.4(0.5)$ & $12.9(1.1)^{*}$ \\
Pro & $5.6(1.5)$ & $6.2(2.0)$ & $3.0(0.6)$ & $4.1(0.7)$ & $4.7(0.4)$ & $5.1(0.3)$ \\
Gly & $18.0(6.8)$ & $19.6(7.0)$ & $10.5(1.5)$ & $13.5(0.8)$ & $7.4(1.0)$ & $8.4(0.4)$ \\
Ala & $5.8(2.0)$ & $6.5(2.3)$ & $2.6(0.6)$ & $4.1(0.4)$ & $4.4(0.2)$ & $4.7(0.2)^{*}$ \\
Val & $5.5(2.4)$ & $6.0(2.5)$ & $2.1(0.7)$ & $3.1(0.3)$ & $4.5(0.5)$ & $4.3(0.3)$ \\
Ile & $4.9(2.3)$ & $5.5(2.5)$ & $1.2(0.6)$ & $2.6(0.3)$ & $3.3(0.3)$ & $3.5(0.3)$ \\
Leu & $6.8(3.2)$ & $7.8(3.6)$ & $2.3(0.4)$ & $3.6(0.5)$ & $4.7(0.5)$ & $5.1(0.4)$ \\
Tyr & $4.0(1.8)$ & $4.6(2.0)$ & $1.5(0.3)$ & $1.8(0.3)$ & $4.2(0.8)$ & $2.6(0.2)^{*}$ \\
Phe & $4.6(2.2)$ & $5.3(2.4)$ & $1.7(0.2)$ & $2.1(0.4)$ & $4.9(1.0)$ & $3.3(0.3)^{*}$ \\
His & $2.1(1.1)$ & $2.5(1.3)$ & $0.4(0.6)$ & $0.9(0.3)$ & $2.3(0.6)$ & $1.4(0.2)$ \\
Lys & $9.1(4.2)$ & $10.4(4.6)$ & $4.4(0.4)$ & $4.9(0.6)$ & $10.0(1.9)$ & $7.0(0.6)^{*}$ \\
Arg & $7.1(2.5)$ & $8.3(3.0)$ & $2.7(0.8)$ & $5.0(0.6)$ & $5.2(0.3)$ & $6.4(0.4)^{*}$ \\
& & & & & & \\
\hline
\end{tabular}

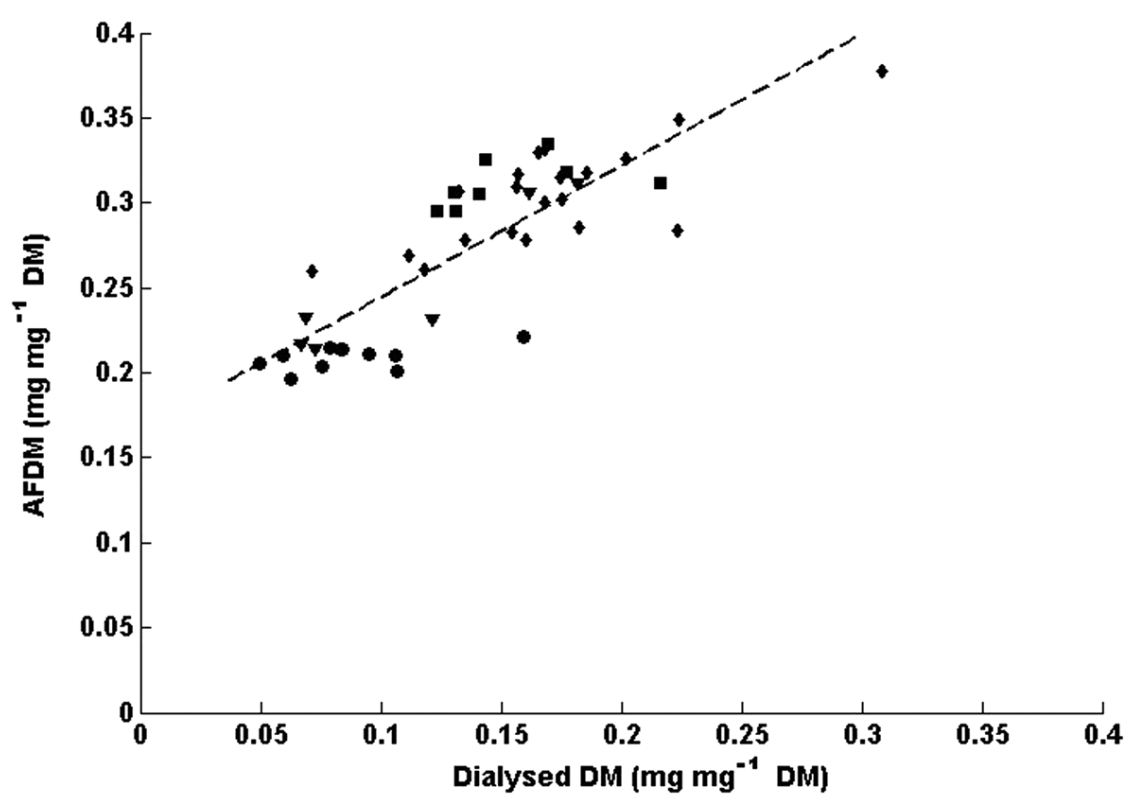

Fig. 2. Organic matter in medusae dry mass determined according to 2 methods: ash-free dry mass (AFDM) and dialysis; expressed as mg of organic matter in mg of dry mass (DM) (linear relationship: slope $=0.77$, intersection $\left.=0.17 ; \mathrm{r}^{2}=0.78\right)$. $\bullet$ : Aurelia aurita; $\mathbf{v}$ : Chrysaora hysoscella; $\mathbf{m}$ : Pelagia noctiluca; $\bullet$ Rhizostoma pulmo tion of S-O bonds and also for C-O vibrations. When the ratio of absorption of amide $\mathrm{N}-\mathrm{H}\left(\mathrm{A}_{\mathrm{N}-\mathrm{H} i}\right.$ scissoring at $1635 \mathrm{~cm}^{-1}$, characteristic for proteins) and the absorption of $\mathrm{S}-\mathrm{O}$ bond vibration $\left(\mathrm{A}_{\mathrm{S}-\mathrm{O}}\right.$ at $1120 \mathrm{~cm}^{-1}$, characteristic for sulphate) was plotted against the molar $\mathrm{C} / \mathrm{S}$ and the molar N/S ratios (Fig. 4), it showed the difference in biochemical composition between the species and the treatment (dialysed vs. non-dialysed): C. hysoscella, $P$. noctiluca and $R$. pulmo grouped together with similar $\mathrm{A}_{\mathrm{N}-\mathrm{H}} / \mathrm{A}_{\mathrm{S}-\mathrm{O}}$ ratio and N/S and C/S molar ratios, while A. aurita had lower $\mathrm{C} / \mathrm{S}$ and N/S ratios indicating low organic (i.e. $\mathrm{C}$ and $\mathrm{N}$ ) and high inorganic $\mathrm{S}$ content. The elemental composition of $A$. aurita was similar to that of the Hydromedusae Aequorea forskalea rather than the other Scyphomedusae investigated (Table 3). After dialysis, the C/S and N/S molar ratios increased in all samples. For all Scyphomedusae species, the $\mathrm{A}_{\mathrm{N}-\mathrm{H}} / \mathrm{A}_{\mathrm{S}-\mathrm{O}}$ ratio decreased in dialysed samples (Fig. 4, filled symbols). This is probably due to the higher content of organic matter in dialysed samples indicated by higher \%C (Table 3), which is reflected in the higher absorption of $\mathrm{C}-\mathrm{O}$ bond vibration present in proteins (Barth 2007). Nevertheless, the biochemical composition of the dialysed $A$. aurita and $A$. forskalea samples was more similar to non-dialysed rather than dialysed C. hysoscella, $P$. noctiluca and $R$. pulmo. According to elemental analysis, $\mathrm{C}$ and $\mathrm{N}$ content for dialysed $A$. aurita, similar to the Hydromedusae $A$. forskalea, was significantly lower in $\mathrm{C}$ and $\mathrm{N}$ content compared to $C$. hysoscella, P. noctiluca and R. pulmo (ANOVA, $\mathrm{p}<$ 0.001) (Table 3). Among the dialysed samples R. pulmo had the highest organic content (ANOVA, $\mathrm{p}<0.001$ and $\mathrm{p}<0.05$ for $\mathrm{N}$ and $\mathrm{C}$, respectively) (Table 3 ) with the highest C/S and N/S molar ratios.

On the basis of these results we speculate that dialysis had not removed sulphate completely. Our speculation was further supported by the difference in elemental composition among A. aurita collected in environments with different salinity: 17, 35 and 38 (the Black Sea, the 

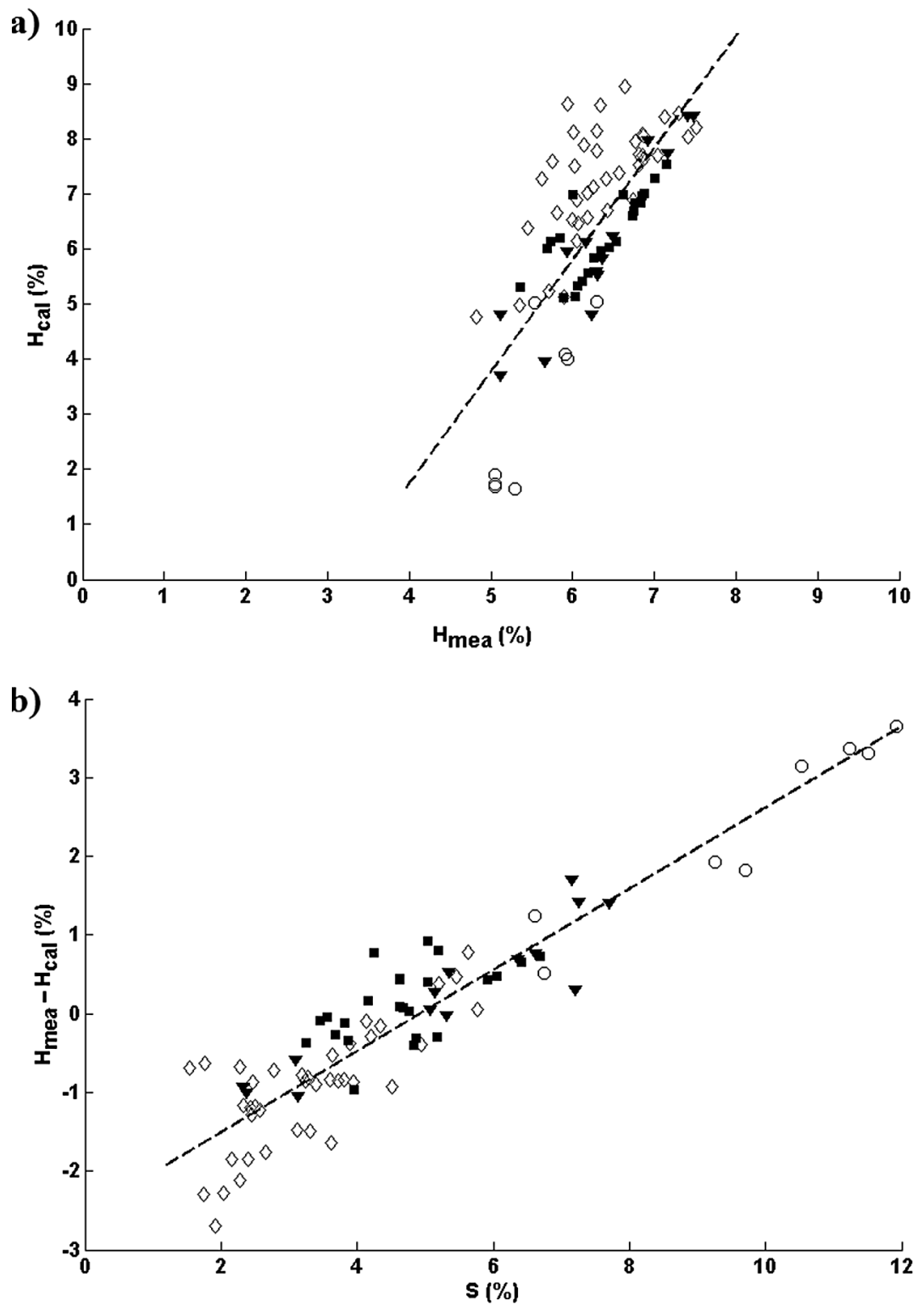

Fig. 3. (a) Measured $\left(\mathrm{H}_{\text {mea }}\right)$ and calculated $\left(\mathrm{H}_{\text {cal }}\right)$ amount of hydrogen in samples showing linear relationship (slope $=2.1$, intersection $=-6.6 ; \mathrm{r}^{2}=$ 0.63 ); and (b) difference in measured and calculated hydrogen in relation to sulphur content (linear relationship: slope $=0.44$, intersection $=-2.3$; $\left.\mathrm{r}^{2}=0.85\right)$. ○: Aurelia aurita; $\mathbf{v}$ : Chrysaora hysoscella; $\mathbf{n}:$ Pelagia noctiluca; $\diamond:$ Rhizostoma pulmo

northern Adriatic and the southern Adriatic [Mediterranean Sea], respectively). To avoid the possible effect of medusae bell diameter on biochemical composition (Lucas 1994) only medusae of similar size were compared. Elemental composition differed between locations of the 2 salinity extremes, 17 and 38 (Table 4), with the FD A. aurita collected at a salinity of 17 showing higher $\mathrm{C}$ and $\mathrm{N}$ contents $(3.2 \%$
$[ \pm 0.5] \mathrm{C}$ and $0.8 \%[ \pm 0.1] \mathrm{N})$ than specimens of the same species collected at a salinity of $38(1.1 \%[ \pm 0.3] \mathrm{C}$ and $0.3 \%$ $[ \pm 0.1] \mathrm{N})$. In contrast, DM expressed as $\% \mathrm{WM}$ was significantly lower for medusae (bell diameters ranging 5-15 $\mathrm{cm}$ ) collected at a salinity of $17(1.8 \pm 0.1 \%)$ compared to medusae from an ambient salinity of $38(3.5 \%[ \pm 0.7])$. After dialysis, the elemental composition of $A$. aurita from different salinities was similar and the molar $\mathrm{C} / \mathrm{N}$ ratio remained in the same range as before dialysis. This indicates that there was no selective loss of material during the desalination of the jellyfish material.

To test for possible material loss during dialysis, inorganic nutrients were measured in the dialysate. The amounts of nitrite $\left(\mathrm{NO}_{2}^{-}\right)$and nitrate $\left(\mathrm{NO}_{3}{ }^{-}\right)$in the dialysate of the samples (on average 0.05 $[ \pm 0.01] \mu \mathrm{mol} \mathrm{l}^{-1}$ of $\mathrm{NO}_{2}^{-}$and $0.43[ \pm 0.16]$ $\mu \mathrm{mol} \mathrm{l}^{-1}$ of $\mathrm{NO}_{3}^{-}$) were close to the control values $\left(0.04\right.$ and $0.28 \mu \mathrm{mol} \mathrm{l^{-1 }}$ for $\mathrm{NO}_{2}{ }^{-}$ and $\mathrm{NO}_{3}{ }^{-}$, respectively) and were not considered in the calculation of $\mathrm{N}$ mass budget. Since the dried jellyfish material was diluted in pre-filtered sea water before being dialysed (Step 3b), the values of total nitrogen $\left(\mathrm{N}_{\text {tot }}\right)$ and ammonium $\left(\mathrm{NH}_{4}{ }^{+}\right)$measured in the control (7.94 and $1.19 \mu \mathrm{mol} \mathrm{\textrm {l } ^ { - 1 }}$, respectively) were subtracted from the $\mathrm{N}_{\text {tot }}$ and $\mathrm{NH}_{4}{ }^{+}$values measured in the dialysate of jellyfish samples. During dialysis a higher loss of $\mathrm{N}$ per $\mathrm{mg}$ of DM was detected in the OD samples compared to the FD. The values of $\mathrm{N}_{\text {tot }}$ loss ranged between $7.72( \pm 1.03) \times$ $10^{-3}$ of $\mu \mathrm{g} \mathrm{N}$ per mg DM in A. aurita and $44.34( \pm 8.88) \times 10^{-3}$ of $\mu \mathrm{g} \mathrm{N}$ per $\mathrm{mg} \mathrm{DM}$ in $P$. noctiluca (Table 5).

Nitrogen in $\mathrm{NH}_{4}{ }^{+}$represented $<30 \%$ of $\mathrm{N}_{\text {tot }}$ in the dialysate. In the OD samples there was more $\mathrm{NH}_{4}{ }^{+}$compared to the FD samples, except in the case of $A$. aurita. The values ranged between $5.8 \%( \pm 0.2)$ in $R$. pulmo and $17.4 \%( \pm 6.5)$ in C. hysoscella in FD samples while the values for the OD samples were the lowest for Aurelia (9.8\% [ \pm 3.3$])$ compared to $27.5 \%( \pm 13.4)$ for the OD C. hysoscella. The $\mathrm{N}$ loss during dialysis was the highest in the FD C. hysoscella and R. pulmo samples (Table 5) and it represented $<0.3 \%$ of $\mathrm{N}_{\text {tot }}$ in the sample. 


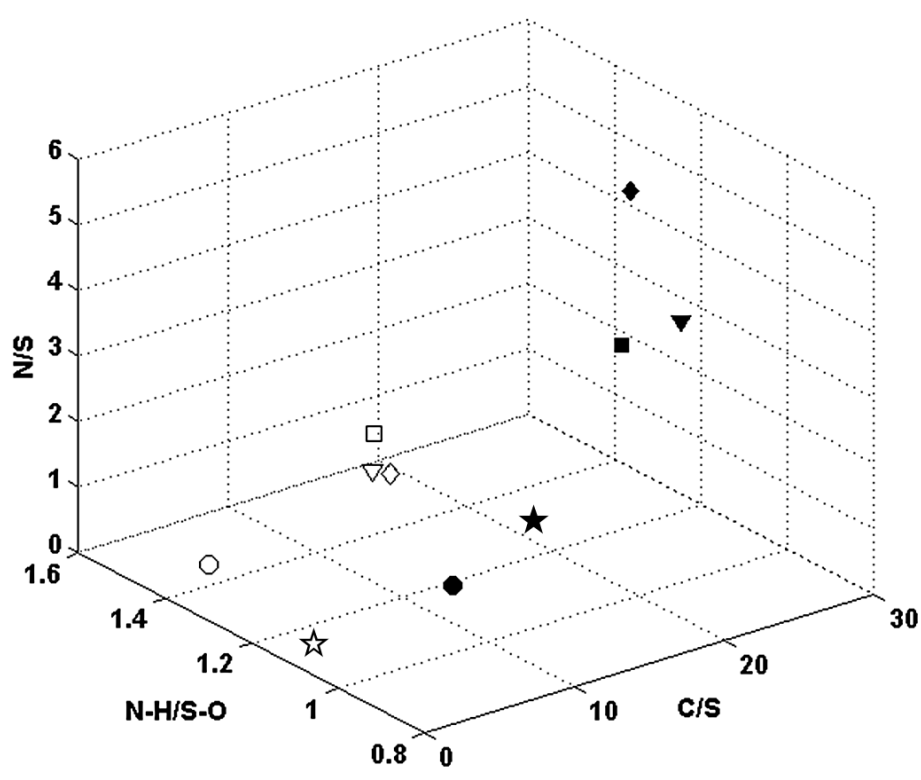

Fig. 4. Ratio of $\mathrm{N}-\mathrm{H}$ bond absorption $\left(A_{\mathrm{N}-\mathrm{H}}\right)$ to $\mathrm{S}-\mathrm{O}$ bond absorption $\left(A_{\mathrm{S}-\mathrm{O}}\right)$ to molar N/S and molar C/S ratio. $\bullet: A u-$ relia aurita; v: Chrysaora hysoscella; $\mathbf{~ : ~ P e l a g i a ~ n o c t i l u c a ; ~}$ •: Rhizostoma pulmo; : Aequorea forskalea; open (filled) symbols: non-dialysed (dialysed) samples

\section{Effects of the sample preparation methods on stable isotope composition $\left(\delta^{13} \mathrm{C}, \delta^{15} \mathrm{~N}\right)$}

Along with the significant differences in medusae elemental composition (Table 1) between the OD and the FD treatments, also the stable isotope composition of non-dialysed OD samples differed from the FD samples for some species. There was no significant difference between the treatments with respect to the $\delta^{13} \mathrm{C}$ ratio of non-dialysed samples (Table 6). On the other hand, the $\delta^{15} \mathrm{~N}$ values were significantly different for R. pulmo and P. noctiluca (ANOVA, $\mathrm{p}<0.01$ ) between the 2 treatments, with the OD samples enriched in ${ }^{15} \mathrm{~N}$. After dialysis, $\delta^{13} \mathrm{C}$ composition did not significantly change in either the OD or the
FD samples, except for $P$. noctiluca (Table 6). Conversely, $\delta^{15} \mathrm{~N}$ significantly increased in dialysed compared to non-dialysed samples for A. aurita (ANOVA, $\mathrm{p}<0.001$ for the OD, $\mathrm{p}<0.01$ for the FD samples) while no significant effect on $\delta^{15} \mathrm{~N}$ after dialysis was observed for the other 3 species. Comparing dialysed OD to dialysed FD samples, no significant difference in $\delta^{15} \mathrm{~N}$ (and $\delta^{13} \mathrm{C}$ ) isotope composition was observed for any of the species.

\section{DISCUSSION}

The majority of the medusa body is composed of mesoglea, a very well hydrated extracellular matrix enveloped by 2 thin layers of tissue: ectodermal and endodermal. Approximately $96 \%$ of their body volume is composed of water, with $\sim 40 \%$ of it as extracellular fluid (Wright \& Purcell 1997). Jellyfish are osmoconformers in their ambient salinity range, therefore the mesogleal extracellular fluid is in osmolar balance with the surrounding seawater (Mills \& Vogt 1984, Wright \& Purcell 1997). Three major components of medusae (water, salt, and a low organic content compared to their volume) distinguish them from crustacean zooplankton. Despite this, the common protocols for biomass estimation and sample processing for biochemical analysis still follow procedures established for crustacean zooplankton.

Zooplankton biomass is most commonly expressed as DM or AFDM. However, several studies indicate that these are poor indicators for gelatinous organisms for at least 2 reasons: (1) biomass varies in relation to ambient salinity (Schneider 1988, Hirst \& Lucas 1998), and (2) the residual water that is bound in DM and AFDM samples leads to the overestimation of jellyfish organic biomass (Larson 1986). Desalting by membrane dialysis was previously used in marine biochemistry (e.g. Zhou et al. 1998, Engel

Table 3. Elemental composition (mean [SD] of $\mathrm{C}, \mathrm{N}$ and $\mathrm{S}$ ) of 4 freeze-dried Scyphomedusae and 1 Hydromedusa (Aequorea forskalea) before and after dialysis. C/N: molar C/N ratio; n: number of samples. Significant difference in elemental composition among species within each treatment: ${ }^{*} \mathrm{p}<0.05,{ }^{* *} \mathrm{p}<0.01,{ }^{* * *} \mathrm{p}<0.001$; ns: non significant. The significant difference between dialysed and nondialysed samples is $\mathrm{p}<0.001$ (not shown)

\begin{tabular}{|c|c|c|c|c|c|c|c|c|c|c|}
\hline \multirow[t]{2}{*}{ Species } & \multirow[b]{2}{*}{$\mathrm{C}(\%)$} & \multicolumn{2}{|c|}{ - Non-dialysed } & \multirow[b]{2}{*}{$\mathrm{C} / \mathrm{N}$} & \multirow[b]{2}{*}{$\mathrm{n}$} & \multirow[b]{2}{*}{$\mathrm{C}(\%)$} & \multirow[b]{2}{*}{$\mathrm{N}(\%)$} & \multirow{2}{*}{$\begin{array}{l}\text { lysed- } \\
\text { S (\%) }\end{array}$} & \multirow[b]{2}{*}{$\mathrm{C} / \mathrm{N}$} & \multirow[b]{2}{*}{$\mathrm{n}$} \\
\hline & & $\mathrm{N}(\%)$ & $\mathrm{S}(\%)$ & & & & & & & \\
\hline Aurelia aurita & $1.9(0.4)$ & $0.5(0.1)^{* *}$ & $2.8(0.5)^{\mathrm{ns}}$ & $4.5(0.2)$ & 12 & $19.3(5.9)^{* * *}$ & $5.0(1.7)^{* * *}$ & $9.7(1.5)^{* * *}$ & $4.5(0.3)^{\mathrm{ns}}$ & 12 \\
\hline Chrysaora hysoscella & $5.0(3.2)$ & $1.3(0.8)$ & $1.8(0.6)^{\mathrm{ns}}$ & $4.7(0.2)$ & 11 & $30.4(8.1)$ & $7.4(1.6)$ & $5.3(1.8)^{\mathrm{ns}}$ & $4.8(0.4)^{\mathrm{ns}}$ & 7 \\
\hline Pelagia noctiluca & $7.3(0.8)^{*}$ & $2.1(0.3)$ & $2.1(0.5)^{\mathrm{ns}}$ & $4.1(0.1)^{* *}$ & 11 & $31.2(3.7)$ & $8.2(1.0)$ & $4.7(0.9)^{\mathrm{ns}}$ & $4.4(0.2)^{\mathrm{ns}}$ & 12 \\
\hline Rhizostoma pulmo & $8.7(2.0)^{* *}$ & $2.5(0.6)$ & $2.7(0.3)^{\mathrm{ns}}$ & $4.1(0.2)^{* *}$ & 18 & $36.6(5.3)^{*}$ & $10.1(1.6)^{* *}$ & $3.3(1.1)^{\mathrm{ns}}$ & $4.2(0.3)^{\mathrm{ns}}$ & 20 \\
\hline Aequorea forskalea & $1.5(0.6)$ & $0.4(0.1)^{* *}$ & $3.2(0.7)^{\mathrm{ns}}$ & $4.8(0.6)$ & 15 & $22.0(8.0)^{* * *}$ & $5.9(2.4)^{* * *}$ & $8.2(2.6)^{* * *}$ & $4.5(0.6)^{\mathrm{ns}}$ & 16 \\
\hline
\end{tabular}


Table 4. Elemental composition (mean [SD] of C, N and S) of Aurelia aurita medusae collected at different ambient salinities: 38, 35 and 17. C/N: C/N molar ratio; n: number of samples. Significant difference in elemental composition between medusae sampled at different salinities: ${ }^{* *} \mathrm{p}<0.01,{ }^{* * *} \mathrm{p}<0.001$; ns: non significant

\begin{tabular}{|c|c|c|c|c|c|c|c|c|c|c|}
\hline \multirow[b]{2}{*}{ Salinity } & \multicolumn{5}{|c|}{ — Non-dialysed- } & \multirow[b]{2}{*}{$\mathrm{C}(\%)$} & \multirow{2}{*}{\multicolumn{2}{|c|}{$\begin{array}{ll} & \\
\mathrm{N}(\%) & \text { Dialysed } \\
\mathrm{S}(\%)\end{array}$}} & \multirow[b]{2}{*}{$\mathrm{C} / \mathrm{N}$} & \multirow[b]{2}{*}{$\mathrm{n}$} \\
\hline & $\mathrm{C}(\%)$ & $\mathrm{N}(\%)$ & $\mathrm{S}(\%)$ & $\mathrm{C} / \mathrm{N}$ & $\mathrm{n}$ & & & & & \\
\hline 38 & $1.1(0.3)^{* * *}$ & $0.3(0.1)^{* * *}$ & $2.8(0.6)^{\mathrm{ns}}$ & $4.6(0.2)^{\mathrm{ns}}$ & 32 & $20.5(4.5)^{\mathrm{ns}}$ & $4.9(1.3)^{\mathrm{ns}}$ & $11.8(1.7)^{* * *}$ & $5.0(0.2)^{\mathrm{ns}}$ & 25 \\
\hline 35 & $1.9(0.4)^{* * *}$ & $0.5(0.1)^{* * *}$ & $2.8(0.5)^{\mathrm{ns}}$ & $4.5(0.2)^{\mathrm{ns}}$ & 12 & $19.3(5.9)^{\mathrm{ns}}$ & $5.0(1.7)^{\mathrm{ns}}$ & $9.7(1.5)^{* * *}$ & $4.5(0.3)^{\mathrm{ns}}$ & 12 \\
\hline 17 & $3.2(0.5)^{* * *}$ & $0.8(0.1)^{* * *}$ & $2.1(0.5)^{* *}$ & $4.5(0.4)^{\mathrm{ns}}$ & 19 & $21.4(4.5)^{\mathrm{ns}}$ & $5.4(1.1)^{\mathrm{ns}}$ & $7.4(1.4)^{* * *}$ & $4.6(0.2)^{\mathrm{ns}}$ & 14 \\
\hline
\end{tabular}

Table 5. Nitrogen lost during dialysis of freeze-dried (FD) and oven-dried (OD) samples. $\mathrm{N}_{\text {tot }}$ : nitrogen determined as total N; $\mathrm{N}_{\mathrm{NH} 4} / \mathrm{N}_{\text {tot }}$ : ratio of nitrogen determined as ammonium and as total nitrogen; \% $\mathrm{N}$ lost: total nitrogen lost during dialysis as percentage of total $\mathrm{N}$ determined by elemental analysis in samples prior to dialysis. Note that the values obtained for the control were subtracted prior to calculations

\begin{tabular}{|c|c|c|c|c|c|c|}
\hline \multirow{2}{*}{ Species } & \multicolumn{2}{|c|}{ 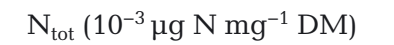 } & \multicolumn{2}{|c|}{$\mathrm{N}_{\mathrm{NH} 4} / \mathrm{N}_{\mathrm{tot}}(\%)$} & \multicolumn{2}{|c|}{$\% \mathrm{~N}$ lost } \\
\hline & OD & FD & OD & FD & OD & FD \\
\hline Aurelia aurita & $8.96(0.93)$ & $7.72(1.03)$ & $9.8(3.3)$ & $11.9(2.6)$ & $0.18(0.04)$ & $0.16(0.01)$ \\
\hline Chrysaora hysoscella & $34.26(20.38)$ & $25.92(18.05)$ & $27.5(13.4)$ & $17.4(6.5)$ & $0.19(0.04)$ & $0.14(0.05)$ \\
\hline Pelagia noctiluca & $44.34(8.88)$ & $16.19(1.96)$ & $16.8(2.7)$ & $14.9(4.8)$ & $0.29(0.04)$ & $0.08(0.01)$ \\
\hline Rhizostoma pulmo & $37.59(1.47)$ & $25.96(7.44)$ & $10.8(1.8)$ & $5.8(0.2)$ & $0.21(0.05)$ & $0.11(0.02)$ \\
\hline
\end{tabular}

\& Händel 2011) when salt ions in the sample interfered with the analyses. During dialysis of jellyfish material $<0.3 \%$ of total $\mathrm{N}$ was lost (Table 5 ) and the $\mathrm{C} / \mathrm{N}$ ratio remained in the same range as before dialysis (Tables $3 \& 4$ ). AFDM was on average 2.2-fold higher when compared with the dialysed jellyfish material, but the standardised AFDM to mass of dialysed jellyfish material relationship was linear (Fig. 2). We therefore concluded that the reduction of the mass during dialysis was due to the inorganic component of the jellyfish dry mass. In this study we used $\mathrm{S}$ as a proxy to follow the efficiency of the salts' removal. After dialysis, the $\mathrm{C}$ content in jellyfish material increased significantly and was in the lower range of the $\mathrm{C}$ content for some non-gelatinous organisms such as copepods $(32.2-67.5 \% \mathrm{C}$, summarized in Harris et al. 2000). Nevertheless, the S con- tent in the samples was still relatively high compared to $\mathrm{C}$ (Tables $3 \& 4$ ). Organic $\mathrm{S}$ content in some invertebrates (bivalves and gastropods) was reported to be $1.4 \%$ of DM (Vetter 1985), forming organic substances such as sulphur amino acids, mucopolysaccharides and sulpholipids. The values exceeding the values of tissue organic $S$ determined in our study is probably due to inorganic $\mathrm{S}$ bound as sulphate. We hypothesize that sulphate ions might form covalent bonds with surface-active polysaccharides (Zhou et al. 1998) of the jellyfish tissue or its mucus and therefore sulphate could not be completely eluted during dialysis. Further analysis and characterisation of jellyfish carbohydrates and in particular mucus are needed to test this hypothesis.

Planktonic gelatinous organisms regulate buoyancy by isoosmotic replacement of sulphate and chloride

Table 6. Stable isotope ratios of carbon $\left(\delta^{13} \mathrm{C}\right)$ and nitrogen $\left(\delta^{15} \mathrm{~N}\right)$ composition of oven-dried (OD) and freeze-dried (FD) Scyphomedusae. Dial: dialysed samples. Means (SD) of 3 samples per species per treatment. Significant differences in stable isotope composition between the 2 drying treatments are given in the p column. Significant differences between dialysed and non-dialysed samples are marked next to the values for dialysed samples. ${ }^{*} \mathrm{p}<0.05,{ }^{* *} \mathrm{p}<0.01,{ }^{* * *} \mathrm{p}<0.001$, ns: non significant

\begin{tabular}{|c|c|c|c|c|c|c|c|c|c|c|c|c|}
\hline & \multicolumn{3}{|c|}{ Aurelia aurita } & \multicolumn{3}{|c|}{ Chrysaora hysoscella } & \multicolumn{3}{|c|}{ Pelagia noctiluca } & \multicolumn{3}{|c|}{ Rhizostoma pulmo } \\
\hline & OD & FD & $\mathrm{p}$ & OD & FD & $\mathrm{p}$ & OD & FD & $\mathrm{p}$ & OD & FD & $\mathrm{p}$ \\
\hline$\delta^{13} \mathrm{C} \%$ & $-22.3(0.1)$ & $-22.6(0.6)$ & ns & $-21.6(1.2)$ & $-21.7(1.1)$ & ns & $-18.8(0.3)$ & $-19.1(0.3)$ & ns & $-19.8(1.1)$ & $-19.1(1.0)$ & ns \\
\hline$\delta^{13} \mathrm{C}_{\text {Dial }} \%$ & $-22.5(0.3)^{\mathrm{ns}}$ & $-22.3(0.1)^{\mathrm{ns}}$ & ns & $-22.8(1.5)^{\mathrm{ns}}$ & $-22.6(1.4)^{\mathrm{ns}}$ & ns & $-20.6(0.1)^{* * *}$ & $-19.9(0.1)^{* *}$ & ns & $-20.1(1.2)^{\mathrm{ns}}$ & $-19.4(1.0)^{\mathrm{ns}}$ & ns \\
\hline$\delta^{15} \mathrm{~N} \%$ & $6.1(0.4)$ & $5.8(0.8)$ & ns & $8.7(0.5)$ & $8.8(0.7)$ & ns & $6.1(0.9)$ & $3.6(0.1)$ & $* *$ & $10.1(0.5)$ & $7.9(0.6)$ & $* *$ \\
\hline$\delta^{15} \mathrm{~N}_{\text {Dial }} \%$ & $8.4(0.1)^{* * *}$ & * $8.0(0.2)^{* *}$ & ns & $10.7(1.2)^{\mathrm{ns}}$ & $10.5(1.1)^{\mathrm{ns}}$ & ns & $5.2(0.5)^{\mathrm{ns}}$ & $4.4(0.4)^{\mathrm{ns}}$ & ns & $9.6(0.4)^{\mathrm{ns}}$ & $8.8(0.7)^{\mathrm{ns}}$ & ns \\
\hline
\end{tabular}


ions (Robertson 1949, Bidigare \& Biggs 1980, Mills \& Vogt 1984). The amount of sulphate determined in jellyfish mesoglea is lower than that of the ambient seawater (Bidigare \& Biggs 1980, Mills \& Vogt 1984, Newton \& Potts 1993, Wright \& Purcell 1997) and differs according to Scyphomedusae species. For example, in the Scyphomedusa Chrysaora quinquecirrha the amount of sulphate represents between 66 and $70 \%$ of seawater levels in the salinity range of 12 to 20 (Wright \& Purcell 1997). Newton \& Potts (1993) reported mesogleal sulphate levels of $40 \%$ and $52 \%$ of seawater levels in Cyanea capillata and Rhizostoma pulmo, respectively. A similar value was obtained for Aurelia aurita sulphate, that is $47 \%$ lower than in the surrounding water (Robertson 1949). Similar to the sulphate ion, concentrations of other ions in the mesoglea - such as magnesium, sodium, calcium and potassium-differ between jellyfish (Mills \& Vogt 1984). The difference in salt content, together with the difference in biochemical composition have a significant effect on the salt to organic matter ratio in dry jellyfish biomass. Our results confirmed that the AFDM to dialysed jellyfish material mass ratio differs among the 4 species of Scyphomedusae. The difference between measured and calculated $\mathrm{H}$ content increased with increasing $\mathrm{S}$ content in dialysed medusae material. This confirms that the jellyfish biomass with higher sulphate content has a greater amount of water bound as hydrated salts. The AFDM of the species with higher salt content in their dried material would be higher due to the greater water content bound in hydrated salts that is combusted together with the organic matter. This results in the difference of the AFDM to dialysed jellyfish material ratio among the 4 species. This ratio was $>1$ in all analysed samples. Since there was no major loss of organic material during dialysis, we think that the AFDM gives an overestimated value of organic content in jellyfish. AFDM is calculated as the difference between DM and the mass of the ash that remains after combustion of the samples at $500^{\circ} \mathrm{C}$. Besides the organic matter, the water bound in the inorganic part of the jellyfish dry mass in the form of hydrated salts is also lost during combustion (Larson 1986). The organic matter content calculated as AFDM is therefore overestimated and the overestimation is higher for the species with higher inorganic content in their dry mass. Indeed, in our study the error due to the overestimation of organic matter determined as AFDM was higher in A. aurita compared to the other species. Furthermore, higher $\mathrm{S}$ content and low $\mathrm{C}$ and $\mathrm{N}$ content in A. aurita dry and dialysed material was observed, indicating that this species' dry mate- rial is particularly rich in salts and depleted in organic material compared to medusae of other species. The estimated organic content of $A$. aurita sampled at different salinities varied, with medusae sampled at lower ambient salinity being enriched in $\mathrm{C}$ and $\mathrm{N}$ content compared to medusae from higher ambient salinity. Nevertheless, the amount of $\mathrm{C}$ and $\mathrm{N}$ in dialysed material did not differ significantly, confirming the observations from previous studies that DM and ash mass (AM) of medusae increase with increasing salinities (Schneider 1988, Hirst \& Lucas 1998). Very often, conversions such as WM to DM, WM to elemental C and $\mathrm{N}$ or DM to elemental $\mathrm{C}$ and $\mathrm{N}$ are used when quantifying elemental and energy flows of jellyfish in marine food webs. In the present study we confirmed that biomass in terms of dry mass and organic content expressed as organic content (AFDM) and C content vary with ambient salinity. Similar to the study by Hirst \& Lucas (1998), the DM as \% of WM changed by $\sim 1 \%$ per 10 salinity units: from, on average, $1.8( \pm 0.1) \% \mathrm{WM}$ at a salinity of 17 to $3.5( \pm 0.7) \% \mathrm{WM}$ at salinity 38 . The difference in relative $\mathrm{C}$ content was even higher $(3.2 \%[ \pm 0.5]$ and $1.1 \%[ \pm 0.3]$, respectively). Therefore, we suggest that when conversions to quantify the biomass of gelatinous organisms are made, the ambient salinity should be considered.

To the best of our knowledge, there have been only a few investigations into the effect of drying on the biochemical composition of planktonic organisms (e.g. Omori 1978, Carabel et al. 2006). Along with the significant difference in the elemental composition between the OD and the FD samples, detailed investigation revealed changes in the composition of the jellyfish amino acid (AA) pool, and changes in stable $\delta^{15} \mathrm{~N}$ nitrogen isotope composition. The total jellyfish AA pool composition in our study did not differ among the species. Despite this similarity in average total AA pool composition, the effect of different drying procedures on total AA pool composition varied among species. During heating to up to $120^{\circ} \mathrm{C}$, most AA remained stable (Weder \& Sohns 1983); therefore, the changes in AA pool composition detected in our study may be due to the microbial degradation of jellyfish organic matter, occurring due to non-sterile conditions during our experiment. The excreted $\mathrm{NH}_{4}{ }^{+}$ is probably produced by microbes in the ammonification process (conversion of organic nitrogen back to $\mathrm{NH}_{4}{ }^{+}$by microbes) and lost during oven-drying. Preferential retention of ${ }^{15} \mathrm{~N}$ and excretion of ${ }^{14} \mathrm{~N}$ takes place during nitrogen cycling in metabolic pathways (Fry 2006); thus, the nitrogen loss as ammonia would lead to an enrichment in ${ }^{15} \mathrm{~N}$ in the OD compared 
to the FD material. According to previous studies (McClelland \& Montoya 2002, Chikaraishi et al. 2009) bulk $\delta^{15} \mathrm{~N}$ tissue composition differs from $\delta^{15} \mathrm{~N}$ in individual AA. Lys, Phe, Tyr and methionine are believed to undergo little or no transamination in consumers while other AA like alanine, glutamate and aspartate are central to nitrogen cycling in and out of the AA pool and therefore are strongly enriched in ${ }^{15} \mathrm{~N}$ relative to the source. Glutamic acid is the crucial AA entering into a variety of transamination metabolic reactions to produce other nonessential amino acids and consequently showing the largest degree of fractionation (McClelland \& Montoya 2002, Chikaraishi et al. 2009, Hannides et al. 2009). The change in ratios between the ${ }^{15} \mathrm{~N}$ enriched (Glx) and ${ }^{15} \mathrm{~N}$-depleted AA (Tyr, Phe, Arg) may lead to the depletion in ${ }^{15} \mathrm{~N}$ of bulk tissue in $C$. hysoscella, $P$. noctiluca and $R$. pulmo. Therefore, even partial changes in the total AA pool during sample preparation can have a significant impact on the $\delta^{15} \mathrm{~N}$ composition of jellyfish tissue. Previous studies revealed that preservation methods and processing might modify the stable isotope composition of the samples (Carabel et al. 2009, Fleming et al. 2011). It is important to emphasize that, in our study, the impact of preservation methods on jellyfish biochemical composition was not tested. However, because subsamples of the same organism were processed separately, the possible change in stable N composition due to storage was uniform among the 2 drying treatments and did not affect the results of our study.

Stable nitrogen and carbon isotopes are often used as biomarkers in ecological studies to trace the source and fate of organic matter along food webs. The nitrogen isotopic composition $\left(\delta^{15} \mathrm{~N}\right)$ of organic material tends to increase from food source to consumer and therefore has been widely used to identify the trophic levels of organisms and their food (Peterson \& Fry 1987). On the other hand, the isotopic composition of a consumer reflects the bulk stable carbon isotope composition $\left(\delta^{13} \mathrm{C}\right)$ of the food source (Peterson \& Fry 1987). When organic matter from different sources shares similar isotopic values, additional elements are useful to determine its source. Stable sulphur isotopes were used to distinguish the benthicpelagic prey contribution to the bulk composition of a predator (Connolly et al. 2004). Our study revealed that jellyfish dry material contains a relatively high amount of sulphate. Therefore, its isotopic value might alter the $\delta^{34} \mathrm{~S}$ of jellyfish material. Indeed, $\delta^{34} \mathrm{~S}$ in non-dialysed jellyfish material ranged between $19.6 \%$ o ( \pm 0.3$)$ and $20.7 \%$ o ( \pm 0.5$)$ in $P$. noctiluca and $A$. aurita, respectively. These values are very close to the $\delta^{34} \mathrm{~S}$ composition of seawater sulphate $(20.99 \%$; Rees at al. 1978). The $\mathrm{S}$ content in dialysed jellyfish material remained relatively high, indicating that not all sulphate was efficiently removed. In a preliminary experiment (data not shown) we dialysed the dried $P$. noctiluca homogenate according to the protocol described above (in 'Materials and methods') and extended the time of the processing to $5 \mathrm{~d}$. The amount of $\mathrm{S}$ was on average $0.9 \%( \pm 0.0)$ and the $\delta^{34} \mathrm{~S}$ values in $P$. noctiluca dialysed material were significantly lower $(16.0 \%$ [ \pm 0.3$])$ than in DM, approaching the values determined for net zooplankton (Peterson 1999). The effect of prolonged dialysis time on material loss was not investigated; therefore, this protocol might influence the stable carbon and nitrogen composition of the dialysed jellyfish material. Nevertheless, our preliminary results suggest that despite high sulphate content in gelatinous organisms, stable S isotope might be applied to study the role of gelatinous plankton in trophic ecology, especially in shallow enclosed areas where the benthic source might be an important jellyfish food source (Pitt et al. 2008).

\section{CONCLUSIONS AND RECOMMENDATIONS}

The population size of gelatinous organisms is hypothesised to increase in the future if anthropogenic stressors such as nutrient inputs, overfishing, proliferation of coastal and offshore constructions and climate change will further change pelagic ecosystems worldwide (Purcell 2012). Therefore, it is fundamental to determine the biomass of gelatinous producers to further estimate their impact on biogeochemical cycling and evaluate their role in food web functioning, both locally and globally. The advent of the first global database of gelatinous plankton abundance and distribution (JeDI; Condon et al. 2012) is an important step toward understanding the spatial and temporal patterns of jellyfish biomass, and the first successful estimate of global carbon biomass of gelatinous plankton and biomass has been recently published (Lucas et al. 2014). Until now, the procedures for the determination of jellyfish biomass and biochemical composition have not been standardised. For this reason, when several datasets of jellyfish biomass are compared or combined, it is necessary to evaluate the historic data that were assessed according to a specific protocol and to implement a standardised sample processing in the future. The present study revealed that traditional methods of sample processing might affect the determination of $\mathrm{C}$ and $\mathrm{N}$ yields, such that a discrepancy of $1 \%$ per 10 
salinity units in the biomass of gelatinous plankton (in terms of DM and C content) may arise if environmental salinity is not considered. Furthermore, the organic matter determined after combustion (AFDM) was overestimated by $51 \%( \pm 13)$ on average, when compared to organic matter of dialysed medusae material. Such a discrepancy in the quantification of $\mathrm{C}$ stored in gelatinous biomass would lead to misinterpretation of the functioning and structure of food webs associated with jellyfish. An overestimation of jellyfish biomass could lead to an underestimation of the $\mathrm{C}$ available to small planktivorous fish and, especially in areas with extensive blooms and an absence of jellyfish predators, to an overestimation of the $\mathrm{C}$ that supports the microbial loop or sinks to the sea bed as the 'jelly-flux' (Condon et al. 2011). During the degradation of labile jellyfish material in the water column or on the sea floor, oxygen is consumed, and remineralization products are released that stimulate primary production. Consistent jellyfish-biomass estimates are therefore required to predict possible hypoxia events, to estimate the extent to which blooms may affect the benthic and pelagic community, and to implement effective precaution strategies.

Together these factors lead to the conclusion that uniform and standardised protocol for assessing the biomass and biochemical composition of gelatinous plankton is essential for understanding the means and the extent to which jellyfish blooms affect the trophic pathways in marine ecosystems, thus altering biogeochemical cycles. We hereby propose a preanalytical processing protocol for jellyfish according to each specific analysis:

(1) Quantification of organic material in jellyfish dry mass. As an effective alternative to AFDM for quantifying organic material in jellyfish dry mass we propose dialysis (Fig. 1, Step 3a).

(2) Biochemical analysis. Protein-rich jellyfish tissue undergoes significant change as a result of ovendrying at $60^{\circ} \mathrm{C}$; therefore, freeze-drying before any biochemical analysis is performed is recommended (Fig. 1, Step 2b).

(3) Stable isotope analysis (SIA). Stable isotope composition should be determined in freeze-dried jellyfish, especially in the case of $\delta^{15} \mathrm{~N}$. Determining the $\delta^{15} \mathrm{~N}$ of ovendried jellyfish material might lead to an incorrect estimation of its trophic position. It should be noted that preservation of samples in ethanol (Carabel et al. 2009) or freezing jellyfish for several months (Fleming et al. 2011) may affect the stable $\mathrm{N}$ composition of gelatinous organisms, and therefore analysis of fresh samples is highly recommended. When organic matter from different sources shares similar $\mathrm{C}$ and $\mathrm{N}$ isotopic composition, $\delta^{34} \mathrm{~S}$ can be used as an additional element to determine its source. In this case, SIA should be performed in 2 steps: (1) the analytical technique enables determination of $\delta^{15} \mathrm{~N}$ and $\delta^{13} \mathrm{C}$ simultaneously; therefore, we recommend determining the stable isotope ratio/ composition of these 2 elements at once in freezedried jellyfish biomass. (2) $\delta^{34} \mathrm{~S}$ should be applied on dialysed jellyfish samples (see Step 1 'Quantification of organic material in jellyfish dry mass' above). The duration of dialysis might be prolonged to efficiently remove the sulphate from freeze-dried jellyfish, taking into consideration that increasing dialysis time might cause changes in the dialysed material and may lead to material loss.

Acknowledgements. This work was supported by the Slovenian Research Agency (program P1-0237). We are grateful for the positive comments from the editor, Dr. Robert Condon and the 3 anonymous reviewers that contributed to the improvement of the manuscript. We thank Tihomir Makovec, Marko Tadejević, Žiga Dobrajc and Franc Kravos for their invaluable help in the field and Milijan Šiško for his assistance in data analysis. T.K. especially thanks Dr. Katja Venko for her essential help and support. We dedicate this work to our dearest friend and colleague Dr. H. W. Mianzan.

\section{LITERATURE CITED}

Alvarez Colombo G, Benović A, Malej A, Lučić D and others (2009) Acoustic survey of a jellyfish-dominated ecosystem (Mljet Island, Croatia). Hydrobiologia 616:99-111

Barth A (2007) Infrared spectroscopy of proteins. Biochim Biophys Acta Bioenerg 1767:1073-1101

Bidigare RR, Biggs DC (1980) The role of sulfate exclusion in buoyancy maintenance by siphonophores and other oceanic gelatinous zooplankton. Comp Biochem Physiol A $66: 467-471$

> Billett DS, Bett MBJ, Jacobs CL, Rouse IP, Wigham BD (2006) Mass deposition of jellyfish in the deep Arabian Sea. Limnol Oceanogr 51:2077-2083

> Brodeur RD, Decker MB, Ciannelli L, Purcell JE and others (2008) Rise and fall of jellyfish in the eastern Bering Sea in relation to climate regime shifts. Prog Oceanogr 77: 103-111

Brotz L, Cheung WWL, Kleisner K, Pakhomov E, Pauly D (2012) Increasing jellyfish populations: trends in Large Marine Ecosystems. Hydrobiologia 690:3-20

> Carabel S, Godínez-Domínguez E, Verísimo P, Fernández L, Freire J (2006) An assessment of sample processing methods for stable isotope analyses of marine food webs. J Exp Mar Biol Ecol 336:254-261

Carabel S, Verísimo P, Freire J (2009) Effects of preservatives on stable isotope analyses of four marine species. Estuar Coast Shelf Sci 82:348-350

Cardona L, Álvarez de Quevedo I, Borrell A, Aguilar A (2012) Massive consumption of gelatinous plankton by Mediterranean apex predators. PLoS ONE 7:e31329

Chikaraishi Y, Ogawa NO, Kashiyama Y, Takano Y and 
others (2009) Determination of aquatic food-web structure based on compound-specific nitrogen isotopic composition of amino acids. Limnol Oceanogr Methods 7 : $740-750$

Condon RH, Steinberg DK, del Giorgio PA, Bouvier TC, Bronk DA, Graham WM, Ducklow HW (2011) Jellyfish blooms result in a major microbial respiratory sink of carbon in marine systems. Proc Natl Acad Sci USA 108: 10225-10230

> Condon RH, Graham WM, Duarte CM, Pitt KA and others (2012) Questioning the rise of gelatinous zooplankton in the world's oceans. Bioscience 62:160-169

Condon RH, Duarte CM, Pitt KA, Robinson KL and others (2013) Recurrent jellyfish blooms are a consequence of global oscillations. Proc Natl Acad Sci USA 110:1000-1005

Connolly RM, Guest M, Melville AJ, Oakes J (2004) Sulfur stable isotopes separate producers in marine foodweb analysis. Oecologia 138:161-167

D'Ambra I, Graham WM, Carmichael RH, Malej A, Onofri V (2013a) Predation patterns and prey quality of medusae in a semi-enclosed marine lake: implications for food web energy transfer in coastal marine ecosystems. J Plankton Res 35:1305-1312

D'Ambra I, Carmichael RH, Graham WM (2013b) Determination of $\delta^{13} \mathrm{C}$ and $\delta^{15} \mathrm{~N}$ and trophic fractionation in jellyfish: implications for food web ecology. Mar Biol 161: 473-480

> DeNiro MJ, Epstein S (1978) Influence of diet on the distribution of carbon isotopes in animals. Geochim Cosmochim Acta 42:495-506

Engel A, Händel N (2011) A novel protocol for determining the concentration and composition of sugars in particulate and in high molecular weight dissolved organic matter (HMW-DOM) in seawater. Mar Chem 127:180-191

> Fleming NEC, Houghton JDR, Magill CL, Harrod C (2011) Preservation methods alter stable isotope values in gelatinous zooplankton: implications for interpreting trophic ecology. Mar Biol 158:2141-2146

Fry B (2006) Stable isotope ecology. Springer Verlag, New York, NY

> Gordoa A, Acuña JL, Farrés R, Bacher K (2013) Burst feeding of Pelagia noctiluca ephyrae on Atlantic bluefin tuna (Thunnus thynnus) eggs. PLoS ONE 8:e74721

Graham WM, Pagés F, Hamner WM (2001) A physical context for gelatinous zooplankton aggregations: a review. Hydrobiologia 451:199-212

Grasshoff K, Ehrhardt M, Kremling K (1983) Methods of seawater analysis, 2 nd revised and extended edn. Verlag Chemie, Weinheim

Grasshoff K, Ehrhardt M, Kremling K (1999) Methods of seawater analysis, 3rd completely revised and extended edn. Wiley-VCH, Weinheim

> Hannides CCS, Popp BN, Landry MR, Graham BS (2009) Quantification of zooplankton trophic position in the North Pacific Subtropical Gyre using stable nitrogen isotopes. Limnol Oceanogr 54:50-61

Harris RP, Wiebe PH, Lenz J, Skjoldal HR, Huntley M (2000) ICES zooplankton methodology manual. Academic Press, San Diego, CA

> Hirst AG, Lucas CH (1998) Salinity influences body weight quantification in the scyphomedusa Aurelia aurita: important implications for body weight determination in gelatinous zooplankton. Mar Ecol Prog Ser 165:259-269 Houghton JDR, Doyle TK, Davenport J, Hays GC (2006) Developing a simple, rapid method for identifying and monitoring jellyfish aggregations from the air. Mar Ecol Prog Ser 314:159-170

Kaehler S, Pakhomov EA (2001) Effects of storage and preservation on the $\delta^{13} \mathrm{C}$ and $\delta^{15} \mathrm{~N}$ signatures of selected marine organisms. Mar Ecol Prog Ser 219:299-304

Kogovšek T, Bogunović B, Malej A (2010) Recurrence of bloom-forming scyphomedusae: wavelet analysis of a 200-year time series. Hydrobiologia 645:81-96

Krishnan S, Perumal P (2013) Preparation and biomedical characterization of jellyfish (Chrysaora quinquecirrha) collagen from southeast coast of India. Int J Pharm Pharm Sci 5:698-701

Larson RJ (1986) Water content, organic content, and carbon and nitrogen composition of medusae from the northeast Pacific. J Exp Mar Biol Ecol 99:107-120

Lebrato M, Pitt KA, Sweetman AK, Jones DOB and others (2012) Jelly-falls historic and recent observations: a review to drive future research directions. Hydrobiologia 690:227-245

> Lucas CH (1994) Biochemical composition of Aurelia aurita in relation to age and sexual maturity. J Exp Mar Biol Ecol 183:179-192

> Lucas CH, Pitt KA, Purcell JE, Lebrato M, Condon RH (2011) What's in a jellyfish? Proximate and elemental composition and biometric relationships for use in biogeochemical studies. Ecology 92:1704

> Lucas CH, Jones DOB, Hollyhead CJ and others (2014) Gelatinous zooplankton biomass in the global oceans: geographic variation and environmental drivers. Glob Ecol Biogeogr 23:701-714

Lynam CP, Gibbons MJ, Axelsen BE, Sparks CAJ, Coetzee J, Heywood GB, Brierley AS (2006) Jellyfish overtake fish in a heavily fished ecosystem. Curr Biol 16:R492-R493

- Madin LP, Cetta CM, McAlister VL (1981) Elemental and biochemical composition of salps (Tunicata: Thaliacea). Mar Biol 63:217-226

Malej A, Faganeli J, Pezdič J (1993) Stable isotope and biochemical fractionation in the marine pelagic foodchain: the jellyfish Pelagia noctiluca and net zooplankton. Mar Biol 116:565-570

McClelland JW, Montoya JP (2002) Trophic relationships and the nitrogen isotopic composition of amino acids in plankton. Ecology 83:2173-2180

Mills CE, Vogt RG (1984) Evidence that ion regulation in hydromedusae and ctenophores does not facilitate vertical migration. Biol Bull 166:216-227

Molinero JC, Casini M, Buecher E (2008) The influence of the Atlantic and regional climate variability on the longterm changes in gelatinous carnivore populations in the northwestern Mediterranean. Limnol Oceanogr 53: 1456-1467

> Newton C, Potts WTW (1993) Ionic regulation and buoyancy in some planktonic organisms. J Mar Biol Assoc UK 73: 15-23

> Omori M (1978) Some factors affecting on dry weight, organic weight and concentrations of carbon and nitrogen in freshly prepared and in preserved zooplankton. Int Rev Hydrobiol 63:261-269

Pauly D, Graham W, Libralato S, Morissette L, Palomares MLD (2009) Jellyfish in ecosystems, online databases, and ecosystem models. Hydrobiologia 616:67-85

Peterson BJ (1999) Stable isotopes as tracers of organic matter input and transfer in benthic food webs: a review. Acta Oecol 20:479-487

Peterson BJ, Fry B (1987) Stable isotopes in ecosystem stud- 
ies. Annu Rev Ecol Syst 18:293-320

Pitt KA, Clement AL, Connolly RM, Thibault-Botha D (2008) Predation by jellyfish on large and emergent zooplankton: implications for benthic-pelagic coupling. Estuar Coast Shelf Sci 76:827-833

Pitt KA, Connolly RM, Meziane T (2009a) Stable isotope and fatty acid tracers in energy and nutrient studies of jellyfish: a review. Hydrobiologia 616:119-132

Pitt KA, Welsh DT, Condon RH (2009b) Influence of jellyfish blooms on carbon, nitrogen and phosphorus cycling and plankton production. Hydrobiologia 616:133-149

Purcell JE (2009) Extension of methods for jellyfish and ctenophore trophic ecology to large-scale research. Hydrobiologia 616:23-50

Purcell JE (2012) Jellyfish and ctenophore blooms coincide with human proliferations and environmental perturbations. Ann Rev Mar Sci 4:209-235

Purcell JE, Arai MN (2001) Interactions of pelagic cnidarians and ctenophores with fish: a review. Hydrobiologia 451: 27-44

Quensen JM, Black RE, Webb KL (1981) Composition of gelatin from developmental stages of the sea nettle, Chrysaora quinquecirrha. Comp Biochem Physiol 70B: 649-651

Rees CE, Jenkins WJ, Monster J (1978) The sulphur isotopic composition of ocean water sulphate. Geochim Cosmochim Acta 42:377-381

Richardson AJ, Bakun A, Hays GC, Gibbons MJ (2009) The jellyfish joyride: causes, consequences and management responses to a more gelatinous future. Trends Ecol Evol 24:312-322

Robertson JD (1949) Ionic regulation in some marine invertebrates. J Exp Biol 26:182-200

Sabatés A, Pagès F, Atienza D, Fuentes V, Purcell JE, Gili JM (2010) Planktonic cnidarian distribution and feeding of Pelagia noctiluca in the NW Mediterranean Sea. Hydrobiologia 645:153-165

Submitted: November 26, 2013; Accepted: July 18, 2014
Schneider G (1988) Chemische Zusammensetzung und Biomasseparameter der Ohrenqualle Aurelia aurita. Helgol Meersunters 42:319-327

Syväranta J, Rautio M (2010) Zooplankton, lipids and stable isotopes: importance of seasonal, latitudinal, and taxonomic differences. Can J Fish Aquat Sci 67:1721-1729

Syväranta J, Harrod C, Kubicek L, Cappanera V, Houghton JDR (2012) Stable isotopes challenge the perception of ocean sunfish Mola mola as obligate jellyfish predators. J Fish Biol 80:225-231

Tinta T, Kogovšek T, Malej A, Turk V (2012) Jellyfish modulate bacterial dynamic and community structure. PLoS ONE 7:e39274

- Uye S (2011) Human forcing of the copepod-fish-jellyfish triangular trophic relationship. Hydrobiologia 666:71-83

Vetter RD (1985) Elemental sulfur in the gills of three species of clams containing chemoautotrophic symbiotic bacteria: a possible inorganic energy storage compound. Mar Biol 88:33-42

Webb KL, Schimpf AL, Olmon J (1972) Free amino acid composition of scyphozoan polyps of Aurelia aurita, Chrysaora quinquecirrha and Cyanea capillata at various salinities. Comp Biochem Physiol B 43:653-663

Weder JKP, Sohns S (1983) Model studies on the heating of food proteins. Amino acid composition of lysozyme, ribonuclease and insulin after dry heating. Z Lebensm Unters Forsch 176:421-425

> West EJ, Welsh DT, Pitt KA (2009) Influence of decomposing jellyfish on the sediment oxygen demand and nutrient dynamics. Hydrobiologia 616:151-160

Wright DA, Purcell JE (1997) Effect of salinity on ionic shifts in mesohaline Scyphomedusae, Chysaora quinquecirrha. Biol Bull 192:332-339

Zhou J, Mopper K, Passow U (1998) The role of surfaceactive carbohydrates in the formation of transparent exopolymer particles by bubble adsorption of seawater. Limnol Oceanogr 43:1860-1871

Proofs received from author(s): September 1, 2014 